\title{
Soil Organic Fractions in Cultivated and Uncultivated Soils of Costal Area in Bangladesh
}

\author{
Ipsita Sarkar, Md. Zulfikar Khan*, Md. Hanif \\ Soil, Water and Environment Discipline, Khulna University, Khulna, Bangladesh \\ Email: ${ }^{\star}$ zulfikar.ku11@gmail.com
}

How to cite this paper: Sarkar, I., Khan, Md.Z. and Hanif, Md. (2019) Soil Organic Fractions in Cultivated and Uncultivated Soils of Costal Area in Bangladesh. Journal of Agricultural Chemistry and Environment, 8, 129-144.

https://doi.org/10.4236/jacen.2019.83011

Received: June 13, 2019

Accepted: August 5, 2019

Published: August 8, 2019

Copyright $\odot 2019$ by author(s) and Scientific Research Publishing Inc. This work is licensed under the Creative Commons Attribution International License (CC BY 4.0).

http://creativecommons.org/licenses/by/4.0/

\begin{abstract}
Assessment of soil organic matter fractions can be instrumental in understanding the causes of limited nitrogen supply, and thus soil fertility restoration. A study was conducted in cultivated and uncultivated saline soil, in order to assay soil organic carbon (SOC), its particle-size fractions and their influence on cultivation and soil fertility at Sundarbans costal area in Bangladesh. Soil samples were taken from the $0-15$ and $15-30 \mathrm{~cm}$ depths from four cultivated fields and from four nearby sites in a native mangrove forest as references. Soil samples were physically fractionated into sand (2000-50 $\mu \mathrm{m})$, silt $(50-2 \mu \mathrm{m})$ and clay $(<2 \mu \mathrm{m})$. Total SOC and $\mathrm{N}$ were analyzed in bulk samples and each size fraction, and the Carbon Management Index (CMI), a widely used indicator of soil quality, was calculated for each field. The CMI in cultivated soils was far below the $100 \%$ in reference soils, reaching $38.16 \%$, $25.70 \%, 32.21 \%$ and $34.43 \%$ in Field 1, Field 2, Field 3 and Field 4 respectively. SOC and $\mathrm{N}$ concentrations decreased in particle size separates in the order clay $>$ silt $>$ sand. The SOC pool and $\mathrm{N}$ in the clay-sized fraction were correlated to soil fertility indicators. More $\mathrm{N}$ was stored in the silt + clay size fractions, a generally more stable pool, than in the more labile sand-sized pool. The SOC pool in sand size fractions was far below in cultivated soils than in a reference uncultivated soil. Thus, the sand-sized pool emerged as the most likely cause of limited $\mathrm{N}$ supply in cultivated soils.
\end{abstract}

\section{Keywords}

Particle Size Fraction, Soil Organic Carbon, Nitrogen, Saline Soil

\section{Introduction}

Soil salinity is a hazard in coastal area just as in Sundarbans in Bangladesh. The Ganges Floodplain in the area includes char land and very young alluvial land 
along the main Ganges channel. The cultivable lands in this region are affected with varying degrees of soil salinity and thus restrict plant growth. Sodium $\left(\mathrm{Na}^{+}\right)$ is the predominant soluble cation in most saline soils of the coastal area [1]. The plants which grow in the saline media exhibit an accumulation of $\mathrm{Na}^{+}$and $\mathrm{Cl}^{-}$ and the reduced uptake of mineral nutrients, especially $\mathrm{Ca}^{2+}, \mathrm{K}^{+}, \mathrm{N}$ and $\mathrm{P}$ [2]. Salt-affected soils exhibit poor soil structure resulting from soil physical processes such as slaking, swelling, and dispersion of clay [3]. Soils of this area are also poor in fertility with low $(1.0 \%-1.5 \%)$ organic matter content. The farmers use chemical fertilizers in an unbalanced proportion as a supplemental source of nutrients [4]. Low SOC concentrations and reduced nutrient retention capacity further increase leaching of applied nutrients and lead to land abandonment by farmers [5].

Particle size fraction of SOC is most related with $\mathrm{N}$ supply and Soil fertility in general. While several studies suggest that the labile SOC associated with sand-sized fractions is the most influential to $\mathrm{C}$ and $\mathrm{N}$ cycling [6]; others have implied a strong role of less labile organic fractions associated with silt and clay-sized particles [7] [8]. As a result, there is a continuous debate among researchers regarding linkages between soil texture, mineralogy, SOC fractions and $\mathrm{N}$ cycling [6]. Furthermore, there is limited knowledge on which particle size fraction of SOC is most related with $\mathrm{N}$ supply and soil fertility and how continuous cultivation affects the distribution of SOC and N in costal soils. Such research efforts would certainly improve the understanding of SOC and $\mathrm{N}$ cycling dynamics in costal soils and provide insights on the best approach to address major nutrient limitation. The main objectives of the research work were: 1) to assess which soil fraction contains the highest level of SOC, 2) to identify the SOC fractions most influential in N supply and soil fertility and 3) To understand how these fractions are affected by cultivation in saline soil.

\section{Materials and Methods}

\subsection{Study Area}

The study was undertaken at Joymany ghol and nearby Sundarbans area of Mongla Upozilla, Bagerhat district which is situated beside the Posur River and directly connected to Bay of Bangle. This study was carried out to investigate the present situation of organic content with salinity in the forest and nearby cultivated areas. This area is selected because about $53 \%$ of the coastal areas of Bangladesh are affected by salinity. Agricultural land use in these areas is very poor, which is much lower than country's average cropping intensity. Salinity causes unfavorable environment and hydrological situation that restrict the normal crop production throughout the year. The factors which contribute significantly to the development of saline soil are tidal flooding during the wet season (from June to October), direct inundation by saline water, and upward or lateral movement of saline ground water during the dry season (from November to May) [9]. According to the farmers most soils of this area had been under culti- 
vation for more than 15 years. But most of the land is now fallow since Aila* (Severe Cyclonic Storm Aila was the worst natural disaster to affect Bangladesh since Cyclone Sidr in November 2007. The second tropical cyclone of the 2009 North Indian Ocean cyclone season, Aila formed over the Bay of Bengal on May 23. A relatively strong tropical cyclone, it caused extensive damage in Bangladesh).

\subsection{Collection of Soil Samples}

The soil samples were collected from four different agricultural field and natural sites. The natural forest sites were bench-marked as reference sites. From each selected site, soil samples were taken from $0-15 \mathrm{~cm}$ (topsoil) and $15-30 \mathrm{~cm}$ (sub soil) depths, using an auger. The sampling sites along with the cropping pattern were shown in Table 1.

\subsection{Preparation of Soil for Chemical Analysis}

The collected soil samples were air dried by spreading on separate sheet of papers after it was transported to the laboratory. After drying in air, the larger aggregates were broken gently by crushing it by a wooden hammer. A portion of the crushed soils was passed through a $2.0 \mathrm{~mm}$ sieve. The sieved soils were then preserved in plastic bags and labeled properly. These were later used for various chemical analyses. The chemical analyses of these collected soil samples were carried out in the laboratory of the Soil Science Discipline, Khulna University.

Table 1. General information about sampling sites.

\begin{tabular}{|c|c|c|c|c|c|c|}
\hline Sample no. & GPS & Physiography & Land type & Fertilizer used & Cropping pattern & $\begin{array}{c}\text { Cultivation } \\
\text { duration }\end{array}$ \\
\hline \multicolumn{7}{|c|}{ Cultivated soils } \\
\hline Field 1 & $22^{\circ} 21.530^{\prime} \mathrm{N} 89^{\circ} 38.068^{\prime} \mathrm{E}$ & & & Urea, TSP, Cow dung & Fallow-Rice-Rice + Shrimp & $\begin{array}{l}\text { About } 10 \text { years, } \\
\text { halt after Aila* } \\
\text { (since 2009), } \\
\text { started again } 2014\end{array}$ \\
\hline Field 2 & $22^{\circ} 21.541^{\prime} \mathrm{N} 89^{\circ} 38.070^{\prime} \mathrm{E}$ & $\begin{array}{l}\text { Gangstidal } \\
\text { floodplain }\end{array}$ & Low land & $\begin{array}{l}\text { Urea, TSP, Cow dung, } \\
\text { Poultry manure, } \\
\text { Compost }\end{array}$ & Vegetables-Rice-Fallow & About 20 years \\
\hline Field 3 & $22^{\circ} 21.530^{\prime} \mathrm{N} 89^{\circ} 38.069^{\prime} \mathrm{E}$ & & & $\begin{array}{c}\text { Urea, TSP, Cow dung, } \\
\text { Poultry manure, } \\
\text { Compost }\end{array}$ & Fallow-Rice-Rice + Shrimp & About 18 years \\
\hline Field 4 & $22^{\circ} 21.520^{\prime} \mathrm{N} 89^{\circ} 38.060^{\prime} \mathrm{E}$ & & & Urea, TSP, Cow dung & Fallow-Rice-Rice + Shrimp & About 18 years \\
\hline \multicolumn{7}{|c|}{ Reference forest soil (mangrove vegetation) } \\
\hline Location 1 & $22^{\circ} 21.54^{\prime} \mathrm{N} 89^{\circ} 38.370^{\prime} \mathrm{E}$ & \multirow{4}{*}{$\begin{array}{l}\text { Gangs tidal } \\
\text { floodplain }\end{array}$} & \multirow{4}{*}{ Low land } & & & \\
\hline Location 2 & $22^{\circ} 21.55^{\prime} \mathrm{N} 89^{\circ} 38.374^{\prime} \mathrm{E}$ & & & & & \\
\hline Location 3 & $22^{\circ} 21.60^{\prime} \mathrm{N} 89^{\circ} 38.76^{\prime} \mathrm{E}$ & & & & & \\
\hline Location 4 & $22^{\circ} 21.60^{\prime} \mathrm{N} 89^{\circ} 38.76^{\prime} \mathrm{E}$ & & & & & \\
\hline
\end{tabular}




\subsection{Analytical Procedure for Soil Analysis}

Measurements of selected physical and chemical properties of the soils were carried out in triplicate according to conventional methods. Electrical conductivity (EC) of soil was estimated by EC meter (Jackson EC meter). The ratio with of soil and water was 1:5 and the result was converted to the ratio of 1:1 (soil: water) as suggested by USDA [10]. pH value of the soil samples was measured by Jackson $\mathrm{pH}$ meter maintaining the ratio of soil to water was 1:2.5 as suggested by Jackson [11]. The CEC of the soils were determined by extracting the soil with ammonium acetate solution $\left(\mathrm{NH}_{4} \mathrm{OAc}\right.$ at $\mathrm{pH}$ 7) along with replacing the ammonium in the exchange complex by $2 \mathrm{M} \mathrm{KCL}$ solution. The displaced ammonium was distilled in for CEC determination in a way similar to the detection of available ammonium nitrogen [12]. Available $\mathrm{K}$ of soil was determined after extraction with from $\mathrm{NH}_{4} \mathrm{OAc}(\mathrm{pH}$ 7.0) as described by Jackson [11]. The extract was then analyzed for available $\mathrm{K}$ by a flame emission spectrometer method at 589 $\mathrm{nm}$ by Jackson [11]. Available Phosphorus was extracted from the soil with 0.5 $\mathrm{M} \mathrm{NaHCO}_{3}$ (Olsen's Method) at $\mathrm{pH} 8.5$ after extraction Molybdophosphoric blue colour method was employed for determination of phosphorus [11]. After extraction with $\mathrm{NH}_{4} \mathrm{OAc}$ ( $\mathrm{pH}$ 7.0), available $\mathrm{Ca}$ and $\mathrm{Mg}$ were determined by titrimetric method as described by Jackson [11]. Organic carbon of the soil sample was estimated by the wet oxidation method of Black [12]. The underlying principle of this method is to oxidize the organic matter with an excess of $\mathrm{K}_{2} \mathrm{Cr}_{2} \mathrm{O}_{7}$ in presence of concentrated $\mathrm{H}_{2} \mathrm{SO}_{4}$ and to titrate the residual $\mathrm{K}_{2} \mathrm{Cr}_{2} \mathrm{O}_{7}$ solution with $0.5 \mathrm{M}$ $\mathrm{FeSO}_{4}$ by Jackson [13]. Total nitrogen content of soil samples was determined by micro-Kjeldahl method as described by Jackson [11] through the digestion of organic matter with concentrated $\mathrm{H}_{2} \mathrm{SO}_{4}$ acid, $\mathrm{H}_{2} \mathrm{O}_{2}$ and catalyst mixture of potassium sulphate $\left(\mathrm{K}_{2} \mathrm{SO}_{4}\right)$, copper sulphate $\left(\mathrm{CuSO}_{4}\right)$ and selenium powder in the ratio of 10:1:1. After completion of digestion, $40 \% \mathrm{NaOH}$ was added with digestion mixture for distillation. The distillate was received in $2 \%$ boric acid $\left(\mathrm{H}_{3} \mathrm{BO}_{3}\right)$ solution with 4 drops of mixed indicator of bromocresol green $\left(\mathrm{C}_{21} \mathrm{H}_{14} \mathrm{O}_{5} \mathrm{Br}_{4} \mathrm{~S}\right)$ and methyl red $\left(\mathrm{C}_{10} \mathrm{H}_{10} \mathrm{~N}_{3} \mathrm{O}_{3}\right)$ solution. Finally, the distillate was titrated with standard $\mathrm{H}_{2} \mathrm{SO}_{4}(0.01 \mathrm{~N})$ until the color changed from green to pink.

\subsubsection{Particle Size Analysis (PSA)}

After removing of binding agents $\left(\mathrm{CaCO}_{3}\right.$ and $\left.\mathrm{OM}\right)$ Particle size analysis of the soil samples were done by hydrometer method as described by Gee and Bauder [14]. Textural class was determined by Marshall's Triangular co-ordinate system.

\subsubsection{Particle-Size Fractionation}

Particle-size fractionation of samples (0 - 15 and $15-30 \mathrm{~cm}$ depths) from cultivated lands and the four sites of forest land was carried out by submerging a $50 \mathrm{~g}$ air-dried sample in deionized water for $30 \mathrm{~min}$ in plastic bottles, and then adding samples of $100 \mathrm{ml}$ of $5 \%$ sodium hexametaphosphate. The bottles were tightly capped and shaken for $16 \mathrm{~h}$ using an end-over-end shaker, and the resulting suspensions were passed through a set of sieves of 2000, 250 and $63 \mu \mathrm{m}$, 
with the help of spraying distilled water and a rubber spatula. The fractions retained on the 250 and $63 \mu \mathrm{m}$ sieves consisted of coarse sand and fine sand, respectively, whereas the material passing the $63 \mu \mathrm{m}$ sieve was the clay + silt suspension. The clay fraction was separated by sonification-sedimentation-siphoning method. The sonification-sedimentation-siphoning process was repeated until the clay was separated completely. After separating clay, the rest of the samples were silt fraction. Total SOC and N concentrations of each size fraction were determined by oxidation method [12] and micro-Kjeldahl method [11] as described before.

The sand-sized organic fraction was considered as labile or particulate component of soil organic matter, while silt- and clay-sized fractions as less-labile fractions [6] [7] [8]. The $\mathrm{C} / \mathrm{N}$ ratio was also computed for bulk soil and particle-size fractions.

\subsection{Computation of Carbon Management Index (CMI)}

The CMI was calculated using the physically fractionated carbon as in Equations (1)-(3) [15]; on the basis of the Carbon Pool Index (CPI) and the Lability Index (LI) [Equation (1)]. Lability Index was computed from the Lability (L) associated with each soil, which in this case is the fraction of the labile $\mathrm{C}$ to non-labile $\mathrm{C}$. The LI is a relative index that gives the fraction (FL) of labile carbon (LC) and non-labile carbon (NLC) from a cultivated field, as compared to a similar fraction (FR) at reference land use [Equation (2)]. This has been applied as a tool for assessing soil quality in terms of increments of total SOC, considering a shift of $\mathrm{C}$ to the labile pool as a result of agricultural practices. High CMI suggests high amounts of carbon associated to sand-sized fraction (labile component), thus high

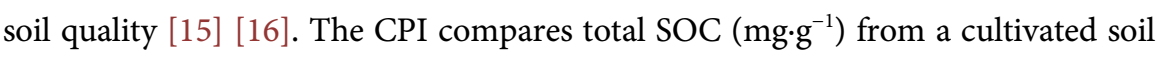
$\left(\mathrm{C}_{\mathrm{S}}\right)$ with total SOC $\left[\mathrm{C}_{\mathrm{R}}\left(\mathrm{mg} \cdot \mathrm{g}^{-1}\right)\right]$ in a reference soil [CR, Equation (3)].

$$
\begin{gathered}
\mathrm{CMI}=\mathrm{CPI} \times \mathrm{LI} \times 100 \\
\mathrm{LI}=\mathrm{FL} / \mathrm{FR} \\
\mathrm{CPI}=\mathrm{C}_{\mathrm{S}}(\text { cultivated soil }) / \mathrm{C}_{\mathrm{R}}(\text { reference soil })
\end{gathered}
$$

\subsection{Statistical Analysis}

With SPSS software version 23 for windows, soil properties of different sites of cultivated soil were analyzed using Analysis of Variance (ANOVA). The ANOVA test also used for significant differences of $\mathrm{C}$ and $\mathrm{N}$ associated with each of the particle-size fractions. Mean values of soil properties and $\mathrm{C}$ and $\mathrm{N}$ concentrations in the particle size fraction were compared using the Fisher's Protected Least Significant of Difference (LSD) at $5 \%$ level of significance.

\section{Results and Discussion}

\subsection{Results}

Soil fertility heterogeneity was evident in all fields after stratification by SOC concentration limits, although soil property EC was not significantly different. 
All other properties such as $\mathrm{pH}$, total SOC, total $\mathrm{N}$, available $\mathrm{P}$, available $\mathrm{K}^{+}$ available $\mathrm{Na}^{+}, \mathrm{Ca}^{2+}$ and $\mathrm{Mg}^{2+}$, CEC were significantly different across the fields (Table 2). Irrespective of soil fertility status, extractable $\mathrm{P}$ was far below the critical concentration of $15 \mu \mathrm{g} \cdot \mathrm{g}^{-1}$ [17].

\subsection{1. $\mathrm{pH}$ and EC}

$\mathrm{pH}$ was significantly different among cultivated fields. The range in cultivated surface soil was 7.67 to 8.10 (Table 2) which is higher than reference soil (8.0). The same results are found for cultivated sub-surface soil.

Electrical conductivity (EC) was the same for all the surface and sub-surface cultivated soils $\left(10.0 \mathrm{dS} \cdot \mathrm{m}^{-1}\right)$. But much higher than uncultivated forest soil. The EC of uncultivated forest surface soil was $7.850 \mathrm{dS} \cdot \mathrm{m}^{-1}$ and sub-surface soil was $7.820 \mathrm{dS} \cdot \mathrm{m}^{-1}$ (Table 2).

\subsubsection{Total Soil Organic Carbon and Total Nitrogen}

Uncultivated soils registered the highest mean SOC, total N. Both SOC and total N were significantly different among the cultivated fields. The highest SOC for surface cultivated soils was found for Field 1 (1.424\%) and the lowest was for Field 2 $(1.307 \%)$ (Table 2 ) as well as the highest SOC for subsurface cultivated soils was found for Field 1 (1.034\%) and the lowest was for Field 3 (0.950\%). SOC for uncultivated forest surface soil was $1.691 \%$ and for subsurface $1.344 \%$ (Table 2).

The highest total $\mathrm{N}$ for surface cultivated soils was found for Field $3(0.159 \%)$ and the lowest was for Field 2 (0.149\%) (Table 2) along with the highest total N for subsurface cultivated soils was found for Field 1 (0.133\%) and the lowest was for Field $3(0.114 \%)$. Total $\mathrm{N}$ for uncultivated forest surface soil was $0.175 \%$ and for subsurface $0.153 \%$ (Table 2).

\subsubsection{CEC and Soil Nutrients ( $\mathrm{P}, \mathrm{K}, \mathrm{Na}, \mathrm{Ca}$ and $\mathrm{Mg}$ )}

The CEC of uncultivated Forest soil is higher than cultivated Field soil. It was 33.25 for surface and 22.75 for subsurface (Table 2). Highest CEC (30 meq/100g soil) was found in Field 4 for cultivated surface soil and $23 \mathrm{meq} / 100 \mathrm{~g}$ soil was for Field 3. For cultivated subsurface soils, highest CEC was found at Field 4 (25 meq/100g soil) and the lowest was at Field 1 (20 meq/100g soil).

The available $\mathrm{P}$ of uncultivated Forest soil is higher than cultivated Field soil. It was $15 \mathrm{ppm}$ for surface and $12 \mathrm{ppm}$ for subsurface. Highest available P (10 ppm) was found in Field 1 for cultivated surface soil whereas the highest available $\mathrm{P}(30 \mathrm{ppm})$ in subsurface cultivated soils was found in Field 1. Consequently, the lowest available P (5.7 ppm) was found in Forest 3 for surface soil and 5.1 ppm in Forest 4 for subsurface soil (Table 2).

Uncultivated soils registered the highest mean of available $\mathrm{K}$ and available $\mathrm{Na}$. Both available $\mathrm{K}$ and $\mathrm{Na}$ were significantly different among the cultivated fields. The highest available $\mathrm{K}$ for surface cultivated soils was found for Field 1 and Field 2 (5848 ppm) and the lowest was for Field 4 (4386 ppm) (Table 2). Meanwhile, the highest available $\mathrm{K}$ for subsurface cultivated soils was found for Field 2 (5555.6 ppm) and the lowest was for Field 4 (4110 ppm). Available K for uncultivated for- 
est surface soil was $6724.90 \mathrm{ppm}$ and for subsurface $5958.33 \mathrm{ppm}$ (Table 2).

The highest available $\mathrm{Na}$ for surface cultivated soils was found for Field 3 (2954.38 ppm) and the lowest was for Field 1 (1342.90 ppm) (Table 2). And the highest available $\mathrm{Na}$ for subsurface cultivated soils was found for Field 2 (2148.65 ppm) and the lowest was for Field 1 and Field 4 (905.74 ppm). Available $\mathrm{Na}$ for uncultivated forest surface soil was $4161.13 \mathrm{ppm}$ and for subsurface 3558.51 ppm (Table 2).

Cultivated soils registered the highest mean of available $\mathrm{Ca}$ and $\mathrm{Mg}$. Both available $\mathrm{Ca}$ and available $\mathrm{Mg}$ were significantly different among the cultivated fields. The highest available Ca for surface cultivated soils was found for Field 2 (0.50\%) and the lowest was for Field1 (0.32\%) (Table 2). Available Ca for subsurface field soils was not significantly varied among themselves. Available Ca for uncultivated forest surface soil was $0.25 \%$ and for subsurface $0.20 \%$ (Table 2).

Highest available Mg for surface cultivated soils was found for Field 1 (0.19\%) and lowest was for Field 2 (0.11\%). Highest $\mathrm{Mg}$ for subsurface cultivated soil found in Field 1 (0.13\%). Available $\mathrm{Mg}$ for uncultivated forest surface soil was $0.08 \%$ and for subsurface $0.030 \%$ (Table 2 ).

Table 2. Mean values of soil properties in $0-15 \mathrm{~cm}$ surface and $15-30 \mathrm{~cm}$ subsurface soil from 4 cultivated and 4 uncultivated sites.

\begin{tabular}{|c|c|c|c|c|c|c|c|c|c|c|c|}
\hline & $\mathrm{pH}$ & $\begin{array}{c}\mathrm{EC} \\
\left(\mathrm{dS} \cdot \mathrm{m}^{-1}\right)\end{array}$ & $\begin{array}{l}\text { Total| } \\
\text { SOC\% }\end{array}$ & $\begin{array}{l}\text { Total } \\
\text { N\% }\end{array}$ & $\begin{array}{l}\text { Available } \\
\text { P (ppm) }\end{array}$ & $\begin{array}{c}\text { Available } \\
\text { K (ppm) }\end{array}$ & $\begin{array}{l}\text { Available } \\
\mathrm{Na} \text { (ppm) }\end{array}$ & $\begin{array}{c}\text { Available } \\
\mathrm{Ca} \%\end{array}$ & $\begin{array}{c}\text { Available } \\
\text { Mg\% }\end{array}$ & $\begin{array}{c}\text { CEC } \\
\text { (meq/100g soil) }\end{array}$ & Texture \\
\hline \multicolumn{12}{|c|}{ Cultivated Soil } \\
\hline \multicolumn{12}{|c|}{ Surface $(0-15 \mathrm{~cm})$} \\
\hline Field 1 & $8.10 \mathrm{a}$ & 10 & $1.424 \mathrm{a}$ & $0.157 \mathrm{ab}$ & $10 \mathrm{a}$ & $5848.0 \mathrm{a}$ & $1342.9 \mathrm{c}$ & $0.32 \mathrm{~d}$ & $0.19 \mathrm{a}$ & $25 b$ & Clay \\
\hline Field 2 & $7.67 \mathrm{~d}$ & 10 & $1.307 \mathrm{~d}$ & $0.149 \mathrm{c}$ & $8 b$ & $5848.0 \mathrm{a}$ & $2148.64 b$ & $0.5 \mathrm{a}$ & $0.11 \mathrm{c}$ & $29 \mathrm{a}$ & Clay \\
\hline Field 3 & $8.00 c$ & 10 & $1.317 \mathrm{c}$ & $0.159 \mathrm{a}$ & $5.7 \mathrm{c}$ & $5637.2 \mathrm{~b}$ & $2954.38 \mathrm{a}$ & $0.37 \mathrm{c}$ & $0.13 b$ & $23 \mathrm{~b}$ & Clay loam \\
\hline Field 4 & $8.05 b$ & 10 & $1.34 \mathrm{~b}$ & $0.152 b c$ & $8 \mathrm{~b}$ & $4386 c$ & $2148.64 b$ & $0.42 b$ & $0.15 b$ & $30 \mathrm{a}$ & Clay loam \\
\hline \multicolumn{12}{|c|}{ Sub-surface $(15-30 \mathrm{~cm})$} \\
\hline Field 1 & $8.34 \mathrm{a}$ & 10 & $1.034 \mathrm{a}$ & $0.133 \mathrm{ab}$ & $6 a$ & $4386 c$ & $905.74 \mathrm{c}$ & $0.3 \mathrm{a}$ & $0.13 a$ & $20 \mathrm{~b}$ & Clay \\
\hline Field 2 & $8.00 \mathrm{~b}$ & 10 & $0.956 \mathrm{~b}$ & $0.121 b c$ & $5.5 \mathrm{~b}$ & $5555.6 \mathrm{a}$ & $2148.65 a$ & $0.28 \mathrm{a}$ & $0.07 \mathrm{~b}$ & $23 \mathrm{a}$ & Clay \\
\hline Field 3 & $8.05 b$ & 10 & $0.95 b$ & $0.114 \mathrm{c}$ & $5.3 \mathrm{~b}$ & $5120.1 \mathrm{~b}$ & $2148.61 b$ & $0.32 \mathrm{a}$ & $0.05 \mathrm{~b}$ & $21 b$ & Clay loam \\
\hline Field 4 & $8.34 \mathrm{a}$ & 10 & $0.961 b$ & $0.14 \mathrm{a}$ & $5.1 \mathrm{~b}$ & $4110 \mathrm{~d}$ & $905.74 \mathrm{c}$ & $0.28 \mathrm{a}$ & $0.08 \mathrm{~b}$ & $25 \mathrm{a}$ & Clay loam \\
\hline \multicolumn{12}{|c|}{ Uncultivated Soil $(\mathrm{n}=4)$} \\
\hline $\begin{array}{c}\text { Forest } \\
\text { surface soil } \\
(0-15 \mathrm{~cm})\end{array}$ & 8.00 & 7.85 & 1.691 & 0.175 & 15 & 6742.9 & 4161.13 & 0.25 & 0.08 & 33.25 & Clay \\
\hline $\begin{array}{c}\text { Forest } \\
\text { sub-surface } \\
(15-30 \mathrm{~cm})\end{array}$ & 8.00 & 7.82 & 1.344 & 0.153 & 12 & 5958.33 & 3558.51 & 0.20 & 0.03 & 22.75 & Clay \\
\hline
\end{tabular}

Here, a, b, c letters represent soil properties that are significantly different among the sites $(\mathrm{p}<0.05)$. Same letters among a column represent no significant differences observed on comparing means using LSD (Least Significant Differences). 


\subsubsection{Carbon and Nitrogen in Particle-Sized Fractions}

In cultivated fields, there was a positive pattern of significant increase in $\mathrm{C}$ and $\mathrm{N}$ concentrations in all particle sizes (Table 3). This was evident in both the topsoil $(0-15 \mathrm{~cm})$ and the lower soil depth $(15-30 \mathrm{~cm})$. And this also related well to the differences in bulk soil C and $\mathrm{N}$ (Table 3). In both cultivated and uncultivated soils, SOC concentrations in the clay-sized fractions were at least fourth times as high as that of sand-sized fractions. This is in accordance with the SOC dilution effect and the high SOC sorption on clays as observed by Zinn et al. [18].

The same occurred for soil $\mathrm{N}$, although with much more intensity, and the clay fraction of cultivated soils showed $\mathrm{N}$ concentrations that were at least three times higher than those in the sand fraction.

The $\mathrm{C} / \mathrm{N}$ ratio in clay-sized fraction of cultivated soils was on average 9 to 6 , lower than what was registered in sand-sized fraction (10 to 14) (Table 4). The $\mathrm{C} / \mathrm{N}$ ratio was $7-10$ in the silt-sized fraction. In top bulk soil $\mathrm{C} / \mathrm{N}$ ratio was 9.07 in Field 1 (contains highest SOC) and 8.77 (contains lowest SOC) in Field 2, but high 9.7 in the uncultivated reference soil.

The clay-sized fraction was the largest SOC pool in cultivated soils, ranging between $46.27 \%$ - 56.63\% in both depths (Figure 1), and Field 3 soil registered the lowest percent share of $\mathrm{C}$ in the sand-sized fraction. However, in the uncultivated soils, the clay-sized SOC pool was generally smaller with slightly more

Table 3. Carbon and nitrogen concentration in sand-sized $(63-2000 \mu \mathrm{m})$, silt-sized (2 $63 \mu \mathrm{m})$ and clay-sized $(<2 \mu \mathrm{m})$ fractions in cultivated and uncultivated soils.

\begin{tabular}{|c|c|c|c|c|c|c|}
\hline \multicolumn{7}{|c|}{$\mathrm{C}$ and $\mathrm{N}$ in particle size fractions\% } \\
\hline & C-Sand & C-Silt & C-Clay & N-Sand & N-Silt & N-Clay \\
\hline \multicolumn{7}{|c|}{ Cultivated soils } \\
\hline \multicolumn{7}{|c|}{$0-15 \mathrm{~cm}$ (Surface) } \\
\hline Field1 & $0.1755 \mathrm{a}$ & $0.521 \mathrm{a}$ & $0.7295 \mathrm{a}$ & $0.0162 \mathrm{~b}$ & $0.0492 \mathrm{~b}$ & $0.0842 \mathrm{~d}$ \\
\hline Field2 & $0.1560 \mathrm{~b}$ & $0.452 \mathrm{ab}$ & $0.6990 \mathrm{ab}$ & $0.0122 \mathrm{c}$ & $0.0480 \mathrm{c}$ & $0.0920 \mathrm{~b}$ \\
\hline Field3 & $0.1463 b$ & $0.450 \mathrm{~b}$ & $0.6710 \mathrm{~b}$ & $0.0101 \mathrm{~d}$ & $0.0497 \mathrm{a}$ & $0.0986 \mathrm{a}$ \\
\hline Field4 & $0.1320 \mathrm{c}$ & $0.369 \mathrm{c}$ & $0.6120 c$ & $0.0210 \mathrm{a}$ & $0.0492 b$ & $0.0910 \mathrm{c}$ \\
\hline \multicolumn{7}{|c|}{$15-30 \mathrm{~cm}$ (Sub-surface) } \\
\hline Field1 & $0.1365 \mathrm{a}$ & $0.312 \mathrm{c}$ & $0.5841 \mathrm{a}$ & $0.0121 b$ & $0.0369 b$ & $0.0742 \mathrm{~b}$ \\
\hline Field2 & $0.1270 \mathrm{~b}$ & $0.322 b$ & $0.5170 \mathrm{c}$ & $0.0180 \mathrm{a}$ & $0.0306 \mathrm{a}$ & $0.0772 \mathrm{a}$ \\
\hline Field3 & $0.1191 c$ & $0.312 \mathrm{c}$ & $0.5270 \mathrm{~b}$ & $0.0118 b$ & $0.0369 \mathrm{~b}$ & $0.0665 c$ \\
\hline Field4 & $0.1107 d$ & $0.331 \mathrm{a}$ & $0.5310 \mathrm{~b}$ & $0.0201 \mathrm{a}$ & $0.0350 \mathrm{a}$ & $0.0741 \mathrm{~b}$ \\
\hline \multicolumn{7}{|c|}{ Uncultivated soils $(\mathrm{n}=4)$} \\
\hline Forest soil $(0-15 \mathrm{~cm})$ & 0.4005 & 0.5107 & 0.7825 & 0.0312 & 0.0543 & 0.0910 \\
\hline Forest soil $(15-30 \mathrm{~cm})$ & 0.2694 & 0.3939 & 0.6677 & 0.0254 & 0.0417 & 0.0830 \\
\hline
\end{tabular}

Here, a, b, c letters represent soil properties that are significantly different among the sites $(p<0.05)$. Same letters among a column represent no significant differences observed on comparing means using LSD (Least Significant Differences). 


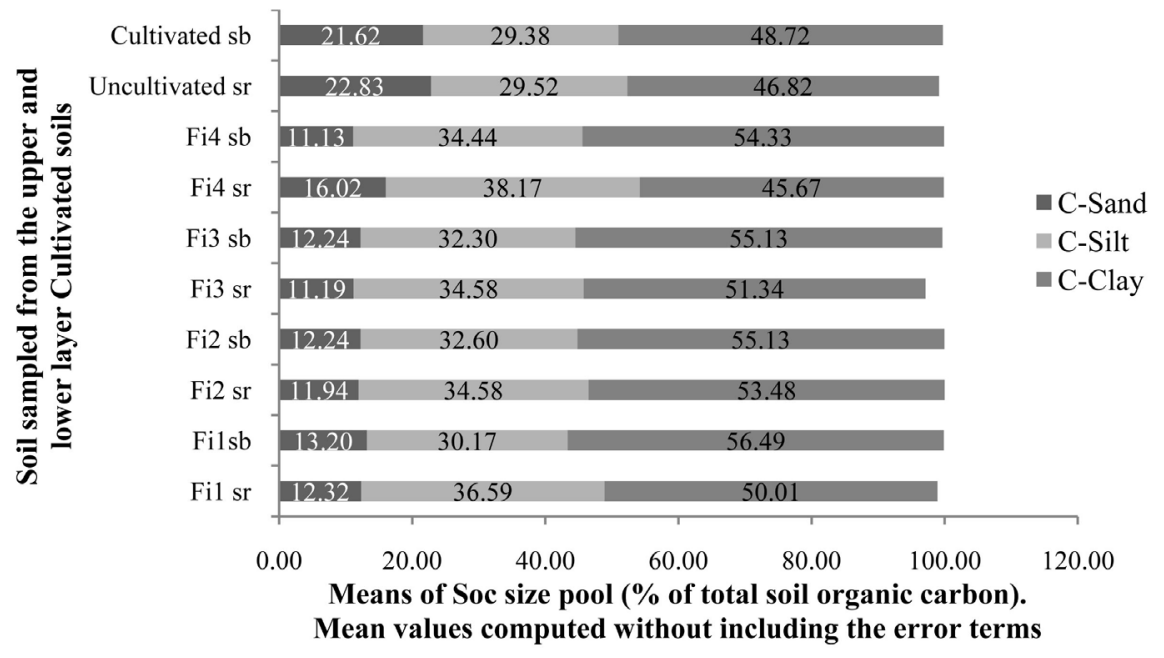

Figure 1. Percent share of carbon in particle-sized fractions as related to total SOC in the bulk soils of different sites sampled at $0-15$ and $15-30 \mathrm{~cm}$ in a cultivated $(\mathrm{n}=4)$ and uncultivated $(\mathrm{n}=4)$ soil.

Table 4. Computed $\mathrm{C} / \mathrm{N}$ ratio derived from $\mathrm{C}$ and $\mathrm{N}$ concentrations of particle size fractions in cultivated and uncultivated soils.

\begin{tabular}{|c|c|c|c|}
\hline & Sand sized $(63-2000 \mu \mathrm{m})$ & Silt sized $(2-63 \mu \mathrm{m})$ & Clay sized $(<2 \mu \mathrm{m})$ \\
\hline \multicolumn{4}{|c|}{ Cultivated soils } \\
\hline \multicolumn{4}{|c|}{$0-15 \mathrm{~cm}$ (Surface) } \\
\hline Field 1 & 10 & 10 & 9 \\
\hline Field 2 & 12 & 9 & 7 \\
\hline Field 3 & 14 & 9 & 6 \\
\hline Field 4 & 12 & 7 & 6 \\
\hline \multicolumn{4}{|c|}{$15-30 \mathrm{~cm}$ (Sub-surface) } \\
\hline Field 1 & 11 & 8 & 7 \\
\hline Field 2 & 9 & 10 & 6 \\
\hline Field 3 & 10 & 8 & 7 \\
\hline Field 4 & 9 & 9 & 7 \\
\hline \multicolumn{4}{|c|}{ Uncultivated soil $\left(\mathrm{n}=4^{\star}\right)$} \\
\hline $0-15$ & 12 & 9 & 8 \\
\hline $15-30$ & 10 & 9 & 8 \\
\hline
\end{tabular}

*4 uncultivated soils from the Sundarbans had taken as references.

total SOC stored in the sand fraction. In the lower depth, there was a general increase in the importance of the silt-sized SOC pool.

A comparison of the different organic carbon indicates cultivated soil 1registered significantly higher CPI, labile C, non-labile C, computed Lability, LI and CMI than other fields, demonstrating variations in SOC quality (Table 5). Only cultivated soil 2 and cultivated soil 3 registered as low lability and lability 
Table 5. Carbon Pool Index (CPI), Carbon Lability (L), Lability Index (LI), and Carbon Management Index (CMI) in $0-15 \mathrm{~cm}$ of cultivated and uncultivated soils.

\begin{tabular}{cccccccc}
\hline & $\begin{array}{c}\text { Total } \\
\text { SOC }\end{array}$ & CPI & Labile C & Non-labile C & Lability & $\begin{array}{c}\text { Lability } \\
\text { Index }\end{array}$ & $\begin{array}{c}\text { Carbon } \\
\text { Management } \\
\text { Index }\end{array}$ \\
\hline $\begin{array}{c}\text { Cultivated } \\
\text { Soil 1 }\end{array}$ & 1.424 & 0.84 & 0.1755 & 1.2505 & 0.1403 & 0.45 & 38.16 \\
$\begin{array}{c}\text { Cultivated } \\
\text { Soil 2 }\end{array}$ & 1.307 & 0.77 & 0.1560 & 1.5150 & 0.1030 & 0.33 & 25.70 \\
$\begin{array}{c}\text { Cultivated } \\
\text { Soil 3 }\end{array}$ & 1.317 & 0.78 & $0 . .1436$ & 1.1210 & 0.1281 & 0.41 & 32.21 \\
$\begin{array}{c}\text { Cultivated } \\
\text { Soil 4 }\end{array}$ & 1.340 & 0.79 & 0.1320 & 0.9810 & 0.1346 & 0.43 & 34.43 \\
$\begin{array}{c}\text { Uncultivated } \\
\text { Soil }\end{array}$ & 1.691 & & 0.4006 & 1.2932 & 0.3097 & & \\
\hline
\end{tabular}

Where CPI (Carbon Pool Index) $=($ SOC in cultivated soil/total SOC in uncultivated); L (Lability) = labile $\mathrm{C} /$ non-labile $\mathrm{C}$; where the non-labile is referred as silt + clay $\mathrm{C}$, and labile $\mathrm{C}$ is referred as sand C. Lability Index $(\mathrm{LI})=$ lability in cultivated soil/lability in uncultivated soil; the CMI (Carbon Management Index) = $\mathrm{CPI} \times \mathrm{LI} \times 100$. Each fertility category consisted of 4 cultivated sites. Four uncultivated soils from the Sundarbans were taken as references.

index. The Carbon Management Index (CMI) was far below 100\% in all the four cultivated fields. The CMI registered was $38.16 \%, 25.70 \%, 32.21 \%$ and $34.43 \%$ for cultivated soil 1, cultivated soil 2, cultivated soil 3 and cultivated soil 4 (Table $5)$.

\subsection{Discussion}

\section{Carbon and Nitrogen in Particle-Sized Fractions}

Routine soil tests in bulk samples indicate that $\mathrm{pH}$, EC, available $\mathrm{P}$, available $\mathrm{K}^{+}$ varied little among fields. This is a consequence of inheritance properties of saline soil. In costal soil, soil salinity is usually combined with high $\mathrm{pH}$ conditions, due to the presence and enrichment of calcium carbonate in the uppermost soil layers (alkaline saline soils) or to hydrolysis of sodium carbonate (sodic soils). In these regions, shallow water tables and improper irrigation practices often accelerate salinization [19].

Monovalent cations such as $\mathrm{Na}^{+}$play a very important role in deflocculating clay particles and consequently increasing the tendency to slake, disperse and swell under specific conditions, so that soils become impermeable and ultimately infiltration and percolation of water cease from the upper surface and within the soils [20] [21]. High salt levels often cause poor physical and chemical soil characteristics including low aggregate stability, impervious subsoil layers, low infiltration rates, low hydraulic conductivities, and soil surface crusting [22] [23].

The data presented in this study express important insights on SOC and $\mathrm{N}$ dynamics in saline soil. However, the significant difference of SOC among fields was used to identify most influential SOC fractions in $\mathrm{N}$ supply and soil fertility. SOC is widely known for its positive influence on aggregate stability, cation ex- 
change and water holding capacity, infiltration, percolation and consequently on soil productivity [8].

Clay-sized fractions have shown high SOC and N concentrations, when compared with the sand-sized-fraction in both cultivated and uncultivated soils. The observed trends of SOC in particle-size fractions agree with Lehmann et al. [24], who found high SOC concentrations in both clay- and silt-sized fractions. The clay fraction is often able to absorb plant-derived aromatics or microbial products [18] across a disparate range of chemical functions and electrical charges. In consequence, the clay is often the richer fraction in SOC, especially in soils with moderate clay contents such as those observed in this study. In addition, some studies in sub-tropical soils assert a direct relationship between SOC and clay contents [8]. However, in the present work, soils have almost the same textural class, which suggests that SOC variability was driven by human-induced practices such as cultivation and use of organic amendments. In fact, base cations such as $\mathrm{Na}^{+}, \mathrm{Ca}^{2+}, \mathrm{Mg}^{2+}$ cultivated than in uncultivated soils, which can be ascribed to some organic fertilizer applications, although this can hardly occur with enhanced SOC depletion due to aggregate disruption by tillage [25].

The SOC concentrations in particle-size fractions are, however, less indicative of SOC retention than the relative pools. The dominant role of the clay-sized fraction in total SOC retention in cultivated soils is shown in Figure 1 and it is clear that SOC bound to silt and especially clay was lost. Similar trends were noted in the $15-30 \mathrm{~cm}$ depth, although the silt-sized fraction was more important than in the topsoil. Feller et al. [26], who noted that most SOC lost with cultivation of clayey soils the losses occurred in the $<2 \mu \mathrm{m}$ size class, with no effect of soil mineralogy. Feller et al. [26] also reported that after adoption of fallow, SOC gains occur in the sand- and clay-size pools in clayey soils. The fact that considerable amounts of SOC are stored in the clay sized fraction explains why bulk SOC and clay contents are related [18]. It is noteworthy that most bars in Figure 1 do not reach $100 \%$ due to the variable recovery of the total SOC after the particle-sized fractionation, and the non-recovered SOC can be safely ascribed to the clay fraction as proposed by Zinn et al. [18]. The data in the present study supports the stated that SOC and $\mathrm{N}$ in silt- and clay-sized fractions are more important to overall soil fertility than the sand-sized fraction. In addition, there is support which stated that the distribution of SOC across particle-size fractions is influenced by cultivation, since the clay-size SOC pool is relatively lower in uncultivated soils.

All cultivated soils had a CMI (Carbon Management Index) $<100 \%$, implying lower amounts of labile C (sand-sized C) and thus a likely poor SOC quality. Organic material applications by farmers in high fertility cultivated soils could not boost the sand-sized C (labile C) to be higher than what was registered in uncultivated soil. This showed that cultivation is a key factor resulting in carbon breakdown and loss; thus, changing to minimal tillage approaches may be attractive for C sequestration [16]. However, the lability indices provide a good basis to detect the changes in active pools of cultivated soils, and this emerged 
crucial for monitoring short-to medium-term $\mathrm{N}$ supply, that would otherwise be difficult using total SOC concentrations and the CPI (Carbon Pool Index). In the present study, potential $\mathrm{N}$ limitations can be associated with low $\mathrm{N}$ supply from low carbon concentrations associated with sand-sized/labile pool, with or without cultivation. In addition, the cultivated soils in low input systems often lack sufficient residue incorporation, which is critical since this is a key entrance pool for building sand-sized SOC pools. The ratio of labile C to non-labile C (lability) further reflected the aforementioned challenge, and this ratio was far less than $50 \%$, clearly demonstrating the dominance of the non-labile $\mathrm{C}$, and the likely less effectiveness of the active pool in $\mathrm{N}$ cycling. In order to improve this labile $\mathrm{N}$ pool, judicious use of organic amendments such as cattle manure and adoption of soil conservation practices such as minimal cultivation must be adopted, in accord with the Integrated Soil Fertility Management approach [27].

The low SOC and N concentrations in the sand-sized fractions, as well as the small relative pools in this size somehow contrast with the often-assumed important role this fraction exerts on $\mathrm{N}$-cycling in the tropics [28]. The computed $\mathrm{C} / \mathrm{N}$ ratio of the sand fraction in top soil was higher (10 to 14 ) than in the clay-sized fraction (Table 4), which is coherent with the fact that this fraction is composed of free particulate organic matter. The increase in $\mathrm{C} / \mathrm{N}$ ratio in silt-sized fraction in the lower soil layer $(15-30 \mathrm{~cm})$ suggests impacts of cultivation, increasing the distribution of $C$ that does not easily mineralize [29]. In the top soil layer, the high $\mathrm{C} / \mathrm{N}$ occurs because, in contrast with the clay-sized organic fraction, there is no possibility of forming mineral organic complex in the sand size that could stabilize organic matter [7]. Besides, the low $\mathrm{C} / \mathrm{N}$ ratio in the clay fraction indicates the high humification degree of constituent organic carbon [7]. Diekow et al. [16] described the sand fraction as the most sensitive pool to soil management, and indeed our data clearly show that this pool was preferentially depleted in cultivated soils, a tendency that has been observed in tropical climate [16]. In consequence, continuous cultivation in the smallholder farming systems can easily disrupt this labile $\mathrm{C}$ component, resulting in overall decline in soil quality.

It was also evident that the clay-sized fraction is even more important for the retention of $\mathrm{N}$ than for SOC. This can perhaps be related to the mechanisms through which SOC is absorbed by clay minerals, chiefly kaolinite and oxides. Similar results were found in different soils in different parts of the world [30] [31]. The low $\mathrm{N}$ concentrations in the silt and especially the sand fractions could be attributed to its mineralization; and the little $\mathrm{N}$ released can be easily lost due to the high precipitation patterns in the region, even in the uncultivated soils [32]. This trend suggests that the clay-sized fraction is the main $\mathrm{N}$ pool in soils and perhaps the main source of $\mathrm{N}$ to plants in low-input, cultivated soils. Consequently, clay-sized SOC can be the fraction most related with chemical fertility, notwithstanding some assertions that this would be a rather recalcitrant or passive pool, unlikely to affect soil productivity within certain agro-ecological zones [33]. Further studies are needed to explore $\mathrm{N}$ release mechanisms from the 
silt and clay fractions to further improve the understanding of $\mathrm{N}$ retention and dynamics in the costal saline soils.

\section{Conclusion}

This study has been conducted to identify the soil fraction containing highest level of soil organic carbon along with influential effect in Nitrogen supply and soil fertility as well as to understand how these fractions are affected by cultivation in saline soil. In this study indicate that the soil organic carbon and nitrogen were significantly decreased after cultivation within the cultivated fields and cultivation decreases the organic matter in soils. It was also observed that silt-sized and clay-sized fraction contained more $O C$ that sand fractions and these two fractions were significantly different within the cultivable fields. In both cultivated and uncultivated soils, SOC concentrations in the clay-sized fractions were at least fourth times as high as that of sand-sized fractions and at least three times for $\mathrm{N}$. The $\mathrm{C} / \mathrm{N}$ ratio in clay-sized fraction of cultivated soils was on average 9 to 6 , lower than what was registered in sand-sized fraction (10 to 14). The $\mathrm{C} / \mathrm{N}$ ratio was 7 - 10 in the silt-sized fraction. The clay-sized fraction was the largest SOC pool in cultivated soils, ranging between $46.27 \%-56.63 \%$ in both depths. However, in the uncultivated soils, the clay-sized SOC pool was generally smaller with slightly more total SOC stored in the sand fraction. In the lower depth, there was a general increase in the importance of the silt-sized SOC pool. In addition, the clay-sized fraction holds most of the total SOC and $\mathrm{N}$ in cultivated soils, and is probably the most important size fraction affecting soil fertility in general. On the contrary, low SOC and $\mathrm{N}$ concentrations in the sand-sized fraction can be a common cause of $\mathrm{N}$ limitations in cultivated and even uncultivated saline soils. Practices that preserve the clay- and silt-sized C organic fraction while increasing SOC pools in the sand size, are the best options to enhance $\mathrm{N}$ supply and crop productivity in the studied soils.

\section{Acknowledgements}

We would like to express our deep gratitude from the core of our heart to the Merciful Creator of the Universe, the most generous and benevolent Almighty, who has given strength to carry on in our hard times and never goes against us although hardly we perform our duty to him. We would like to express our sincere gratitude to our supervisor Associate Professor Md. Hanif for his continuous supervision, guidance, inspiration and thoughtful suggestion during completion of the work. Individual efforts alone can never contribute in totally to a successful completion of any venture. We would be failing in our duty if we did not state our gratitude and appreciation to the following individuals who have made the valuable contribution towards the review work.

\section{Conflicts of Interest}

The authors declare no conflicts of interest regarding the publication of this paper. 


\section{References}

[1] Qadir, M., Oster, J.D., Schubert, S., Noble, A.D. and Sahrawat, K.L. (2007) Phyto-Remediation of Sodic and Saline-Sodic Soils. Advances in Agronomy, 96, 197-247. https://doi.org/10.1016/S0065-2113(07)96006-X

[2] Kaya, C., Kirnak, H. and Higgs, D. (2001) Enhancement of Growth and Normal Growth Parameters by Foliar Application of Potassium and Phosphorus in Tomato Cultivars Grown at High ( $\mathrm{NaCl})$ Salinity. Journal of Plant Nutrition, 24, 357-367. https://doi.org/10.1081/PLN-100001394

[3] Clark, G.J., Dodgshun, N., Sale, P.W.G. and Tang, C. (2007) Changes in Chemical and Biological Properties of a Sodic Clay Subsoil with Addition of Organic Amendments. Soil Biology and Biochemistry, 39, 2806-2817.

[4] BARC (Bangladesh Agricultural Research Council) (2005) Fertilizer Recommendation Guide. BARC Soils No. 45. Bangladesh Agricultural Research Council, Dhaka, Bangladesh.

[5] Woomer, P.L., Tungani, J., Odhiambo, G. and Mwaura, F.M. (2005) Striga Management Options in Western Kenya. African Crop Science Conference Proceedings, 7, $479-484$.

[6] Bayer, C., Martin-Neto, L., Mielniczuk, J., Pillon, C. and Sangoi, L. (2001) Changes in Soil Organic Matter Fractions under Subtropical No-Till Cropping Systems. Soil Science Society of America Journal, 65, 1473-1478. https://doi.org/10.2136/sssaj2001.6551473x

[7] Christensen, B.T. (2001) Physical Fractionation of Soil and Structural and Functional Complexity in Organic Matter Turnover. European Journal of Soil Science, 52, 345-353. https://doi.org/10.1046/j.1365-2389.2001.00417.x

[8] Feller, C. and Beare, M. (1997) Physical Control of Soil Organic Matter Dynamics in the Tropics. Geoderma, 79, 69-116. https://doi.org/10.1016/S0016-7061(97)00039-6

[9] Haque, S.A. (2006) Salinity Problems and Crop Production in Coastal Regions of Bangladesh-A Review Article. Pakistan Journal of Botany, 38, 1359-1365.

[10] USDA (United States Department of Agriculture) (2004) Soil Survey Laboratory Manual, Soil Survey Investigation Report No. 42, Version 4.0. USDA-NRCS, Washington DC.

[11] Jackson, M.L. (1967) Soil Chemical Analysis. Prentice Hall, Englewood cliffs, NJ.

[12] Black C.A. (1965) Method of Soil Analysis. Part I and Part II, American Society of Agronomy, Madison, WI, 371-375.

[13] Jackson, M.L. (1962) Soil Chemical Analysis. Prentice Hall, Inc., Englewood Cliffs, NJ.

[14] Gee, G.W. and Bauder, J.W. (1986) Particle Size Analysis. In: Klute, A., Ed., Methods of Soil Analysis, Agronomy Monograph, 2nd Edition, ASA and SSSA, Madison, WI, 383-411.

[15] Blair, G.J., Lefroy, R.D. and Lisle, L. (1995) Soil Carbon Fractions Based on Their Degree of Oxidation, and the Development of a Carbon Management Index for Agricultural Systems. Crop and Pasture Science, 46, 1459-1466. https://doi.org/10.1071/AR9951459

[16] Diekow, J., Mielniczuk, J., Knicker, H., Bayer, C., Dick, D.P. and Kögel-Knabner, I. (2005) Soil C and N Stocks as Affected by Cropping Systems and Nitrogen Fertilisation in a Southern Brazil Acrisol Managed under No-Tillage for 17 Years. Soil and Tillage Research, 81, 87-95. https://doi.org/10.1016/j.still.2004.05.003

[17] Muslem, M., Farid, A.T., Miah, M.A., Jahiruddin, M., Rahman, A.M., Quayyum, 
M.A., Sattar, M.A., Motalib, M.A., Islam, M.F., Ahsan, M. and Razia, M.S. (2005) Fertilizer Recommendation Guide. Bangladesh Agricultural Research Council, Farmgate, Dhaka, 1215.

[18] Zinn, Y.L., Lal, R., Bigham, J.M. and Resck, D.V. (2007) Edaphic Controls on Soil Organic Carbon Retention in the Brazilian Cerrado: Texture and Mineralogy. Soil Science Society of America Journal, 71, 1204-1214. https://doi.org/10.2136/sssaj2006.0014

[19] Qureshi, R.H. and Barret-Lenard, E.G. (1998) Saline Agriculture for Irrigated Land in Pakistan: A Handbook. ACIAR Monograph No. 50. Australian Centre for International Agricultural Research, Canberra.

[20] Keren, R. (2000) Salinity. In: Sumner, M.E., Ed., Handbook of Soil Science, CRC Press, Boca Raton, FL, 3-25.

[21] Qadir, M. and Schubert, S. (2002) Degradation Process and Nutrient Constraints in Sodic Soils. Land Degradation \& Development, 13, 275-294. https://doi.org/10.1002/ldr.504

[22] Richards, L.A. (1954) Diagnosis and Improvement of Saline and Alkaline Soils. Agriculture Handbook, Vol. 60, USDA, Washington DC, 160 p.

[23] Sharma, B.R. and Minhas, P.S. (2005) Strategies for Management Saline/Alkali Waters for Sustainable Agricultural Production in South Asia. Agricultural Water Management, 78, 136-151. https://doi.org/10.1016/j.agwat.2005.04.019

[24] Lehmann, J., da Silva Cravo, M. and Zech, W. (2001) Organic Matter Stabilization in a Xanthic Ferralsol of the Central Amazon as Affected by Single Trees: Chemical Characterization of Density, Aggregate, and Particle Size Fractions. Geoderma, 99, 147-168. https://doi.org/10.1016/S0016-7061(00)00070-7

[25] Zinn, Y.L., Lal, R. and Resck, D.V.S. (2005) Changes in Soil Organic Carbon Stocks under Agriculture in Brazil. Soil and Tillage Research, 84, 28-40. https://doi.org/10.1016/j.still.2004.08.007

[26] Feller, C., Albrecht, A. and Tessier, D. (1996) Aggregation and Organic Matter Storage in Kaolinitic and Smectitic Tropical Soils. In: Carter, M.R. and Stewart, B.A., Eds., Structure and Organic Matter Storage in Agricultural Soils, Lewis, Boca Raton, FL, 309-359.

[27] Musinguzi, P., Tenywa, J.S., Ebanyat, P., Tenywa, M.M., Mubiru, N.D., Twaha, A.B. and Leip, A. (2013) Soil Organic Carbon Thresholds and Nitrogen Management in Tropical Agroecosystems: Concepts and Prospects. Journal of Sustainable Development, 6, 31-43. https://doi.org/10.5539/jsd.v6n12p31

[28] Olk, D.C. and Gregorich, E.G. (2006) Overview of the Symposium Proceedings, "Meaningful Pools in Determining Soil Carbon and Nitrogen Dynamics". Soil Science Society of America Journal, 70, 967-974. https://doi.org/10.2136/sssaj2005.0111

[29] Pathak, H. and Rao, D.L.N. (1998) Carbon and Nitrogen Mineralization from Added Organic Matter in Saline and Alkali Soils. Soil Biology and Biochemistry, 30, 695-702. https://doi.org/10.1016/S0038-0717(97)00208-3

[30] Chenu, C. and Plante, A.F. (2006) Clay-Sized Organo-Mineral Complexes in a Cultivation Chronosequence: Revisiting the Concept of the 'Primary Organo-Mineral Complex'. European Journal of Soil Science, 57, 596-607. https://doi.org/10.1111/j.1365-2389.2006.00834.x

[31] Basile-Doelsch, I., Brun, T., Borschneck, D., Masion, A., Marol, C. and Balesdent, J. (2009) Effect of Landuse on Organic Matter Stabilized in Organomineral Complex- 
es: A Study Combining Density Fractionation, Mineralogy and $\delta^{13}$ C. Geoderma, 151, 77-86. https://doi.org/10.1016/j.geoderma.2009.03.008

[32] van Keulen, H. (2001) Tropical Soil Organic Matter Modeling: Problems and Prospects. Nutrient Cycling in Agroecosystems, 61, 33-39.

https://doi.org/10.1023/A:1013372318868

[33] Weil, R.R., Islam, K.R., Stine, M.A., Gruver, J.B. and Samson-Liebig, S.E. (2003) Estimating Active Carbon for Soil Quality Assessment: A Simplified Method for Laboratory and Field Use. American Journal of Alternative Agriculture, 18, 3-17. https://doi.org/10.1079/AJAA2003003 